\title{
Trust In A Social Theory Of Currency Crises As Applied To Currency Boards
}

Rae Weston, (E-mail: Rae.weston@mgsm.edu.au), Macquarie Graduate School of Management, Australia

\begin{abstract}
The conventional explanations of currency crises have not proved fruitful Aykens (2005) proposes a social theory of currency crises which he shows is able to account for the interwar gold standard crisis. In this paper we explain the elements of Aykens' theory, propose a brief extension of it and demonstrate with respect to currency boards, specifically those of Bosnia-Herzogovina and of Argentina both how affective trust is achieved and also how it is destroyed.
\end{abstract}

\section{INTRODUCTION}

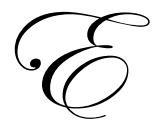

xplanations of currency crises are either policy failure explanations where crisis in a foreign exchange market is the result of domestic policy failure (Flood and Marion (1998); or market power explanations which suggest that it is investors who precipitate the crisis which is generated by profit-driven speculation. Aykens suggests a new theory -a social theory of currency crises which builds on the network and trust literature and which argues that it is changes in trust relations between state and markets actors which is the source of the crises. We explain Aykens' theory and propose a brief extension to it which more explicitly brings in the role of cognitive dissonance. We apply this theory to currency boards and the recent experiences of two currency boards. We show that the currency board of Bosnia-Herzogovina has reached the affective trust stage, and identify how affective trust was reached and then breached in the case of the Argentinian currency board.

\section{AYKENS' THEORY}

Aykens (2005) argues that changes from low levels to high levels of trust between state and market actors embedded in a currency exchange network are able to account for instances of both currency stability and of crisis. This takes up Checkel's (2001@ p 560-1) that rationalists are unable to model interaction contexts where the interests of actors may change.

Leblang (2002) and MacIntyre (2001) have demonstrated that domestic policy-making structures and orientations have impact on the investment decisions of market actors. Nevertheless it is difficult to identify situations where domestic political constraints inhibited the defence of exchange rate policy.

Aykens' theory begins with Cohen's (1998, at p. 12) proposition that "money...is a product of selfreinforcing patterns of market practice and behaviour." He moves from this to the view of social embeddedness theorists such as Uzzi (1996 at p.12) who suggests that the repercussions of continued exchanges among networked firms are that " $(T)$ he calculative orientation of arms-length ties fades and is replaced with a heuristic decision-making process that economizes on cognitive resources, speeds up decision-making, and inclines actors to interpret favourably the actions and intentions of their network partners in ambiguous situations."

Foreign exchange markets are seen to be similar to firms embedded in because networks for three reasons: first because foreign exchange transactions are concentrated among a few global financial institutions and currencies; second, there is a mutual vulnerability to the potential opportunistic behaviour of investors and of policy makers; and third, the complementary resources of state and market actors including money creation, market architecture and financial product creation produce mutually dependent global relations. 
In this theory authority over currency relations is socially constructed through three stages of trust: momentary, reputational and affective. Momentary trust is based on risk calculations made from information only available at the time (moment) of the transaction. Gradually, as Dasgupta (1998) suggests, reputation is ultimately acquired over time through behaviour in well-understood circumstances. Continued compliance with accepted behavioural norms leads to the development of reputational trust. A crucial element of this stage is that market actors begin to withhold judgement in the face of actions that would have been seen as violations of momentary trust because they expect that these actions will move back in the right direction.

Importantly, there is a third stage when affective trust is acquired. Affective trust fosters risk-taking with long time horizons and is highly resistant to new information. When affective trust is violated, according to Lewis and Weigart(1995 at p.971) "we are morally outraged, not just disappointed."

\section{A Brief Extension Of Aykens' Theory}

We are able to extend Aykens' theory here by incorporating a more developed stage which allows us to account more specifically for the precipitous recognition of the moral outrage stance. This requires the recognition of the third stage as providing the basis for disaster myopia.

"Disaster myopia" may be defined as the "systematic tendency to underestimate shock probabilities" .Guttentag and Herring suggest that there are two factors which determine whether knowledge of an event is characterised by risk or uncertainty: the first is the frequency with which the event occurs relative to the frequency of stable for a reasonable length of time. The second factor where it relates to underlying economic or financial processes is subject to considerable uncertainty which could be reduced by an investment in information and analysis. In practice if there is affective trust, proper behaviour is assumed and only real "shocks" will raise doubts.

"Shocks" are defined by Guttentag and Herring ${ }^{1}$ ( p.2) as "events that occur very infrequently and have very large potential effects ".Tversky and Kahneman ${ }^{2}$ (p.64) identify the "availability heuristic " as a description of situations where market actors estimate the frequency of shocks by the ease with which instances or associations can be brought to mind. In these circumstances behaviour is unlikely to change even in the face of evidence that the shock probability has increased. Cognitive dissonance prevents new information from casting doubt on the wisdom of past decisions. .A possible minor event or events escalate to "shock" with very large potential and at first not understood effects as unusual activity is not investigated and escalation of information to market actors does not occur. Inevitably this leads to a very late recognition of serious problems which by that time will be beyond small corrective actions. Moral outrage turns to a withdrawal of trust which has major consequences, as not even momentary trust will now be accorded to the failing-trust market actor.

In the next section we show how this theory applies in the case of currency boards.

\section{CURRENCY BOARDS}

A currency board is a mechanism for transferring the reputation of a reserve currency to a domestic currency. Currency boards have been adopted by Hong Kong (1983), Argentina (1991), Estonia (1992), Lithuania (1994) and Bulgaria (1997). Currency boards have been described by Ghosh, Gulde and Wolff (2000) as "the most extreme form of exchange rate peg" short of adopting a common currency. In essence a currency board has the backing of domestic currency by a foreign anchor currency and free conversion of the domestic currency into the backing currency. A currency board arrangement by definition has to cover a monetary aggregate, but the extent to which it does so depends on how the reserves are defined. Using "net reserves' is likely to improve the credibility of the system. A currency board's reserves must be adequate to ensure that all holders of its notes and coins can convert them into the anchor currency. Currency boards often hold reserves of 105 or 110 percent of their liabilities, in order to have a margin of protection should the bonds they hold lose value. Currency boards typically make profits of about $1 \%$ of GDP a year. Using the currency it issues rather then the anchor currency directly captures seigniorage for the domestic government. 
Under a currency board system the risk of inflation is reduced because the government is only able to finance its spending by taxing or borrowing which is much more limiting than printing money. The currency board does not act as lender of last resort for the economy's banks. While failures have been rare in straight currency board systems, they have been a concern in countries which have had currency-board like systems.

A crucial element for a currency board system is the enshrining of the arrangements in the central bank law. Legal definitions are required for the exchange rate and reserves and for the powers of the managing institution specified under the system. It may be, as the rules governing Lithuania's currency board specify, that the central bank is permitted to appreciate the exchange rate but requires legal action to depreciate it. The central bank should not be able to lend to the government under the currency board arrangement because it may affect transparency.

A currency board is a mechanism for transferring the reputation of a reserve currency to a domestic currency Table 1 lists the currency boards or similar structures in 2002.

\begin{tabular}{|c|c|c|c|c|}
\hline \multicolumn{5}{|c|}{ Currency Boards And Currency Board-Like Systems As Of June 2002} \\
\hline Country & Population & GDP (US\$) & Began & Exchange rate / remarks \\
\hline Bermuda [UK] & 63,000 & $\$ 2$ billion & 1915 & Bermuda \$1 = US\$1 / Loose capital controls \\
\hline Bosnia & 3.8 million & $\$ 6.2$ billion & 1997 & 1.95583 convertible marks $=1$ euro / Currency board-like \\
\hline Brunei & 336,000 & $\$ 5.6$ billion & 1952 & Brunei $\$ 1$ = Singapore $\$ 1 /$ Currency board-like \\
\hline Bulgaria & 7.8 million & $\$ 35$ billion & 1997 & 1.95583 leva $=1$ euro / Currency board-like \\
\hline Cayman Islands [UK] & 35,000 & $\$ 930$ million & 1972 & Cayman $\$ 1=$ US\$1.20 \\
\hline Djibouti & 450,000 & $\$ 550$ million & 1949 & 177.72 Djibouti francs = US\$1 / Currency board-like \\
\hline Estonia & 1.4 million & $\$ 7.9$ billion & 1992 & 8 kroons $=0.51129$ euro $/$ Currency board-like \\
\hline Falkland Islands [UK] & 2,800 & unavailable & 1899 & Falklands $£ 1=$ UK£1 \\
\hline Faroe Islands [Denmark] & 45,000 & $\$ 700$ million & 1940 & 1 Faroese krone $=1$ Danish krone \\
\hline Gibraltar [UK] & 29,000 & $\$ 500$ million & 1927 & Gibraltar $£ 1=$ UK£1 \\
\hline Hong Kong [China] & 7.1 million & $\$ 158$ billion & 1983 & Hong Kong $\$ 7.80=$ US\$1 / More orthodox since 1998 \\
\hline Lithuania & 3.6 million & $\$ 17$ billion & 1994 & 3.4528 litai = 1 euro $/$ Currency board-like \\
\hline
\end{tabular}

A currency board for a transition economy is that established in Bosnia Herzogovina where the Central Bank began operations in August 1997 at the start of the transitions to a new nation and to a market economy from a communist economy. There were four currencies in use at the time-the BIH dinar, the Yugoslav dinar, the Croatian kuna and the DM-but only the latter was accepted as a transaction currency. There were 75 very small local banks but these were not used by most of the population.

A currency board arrangement was established by the CBBH Law and in the Dayton Peace Agreement. This provided a nominal anchor for the currency and a rule-based approach to monetary policy. The CBBH Law specified the convertible mark tied to the DM at 1:1 (changed to the Euro at 1.95583 since January 1999); and that the domestic currency was to be fully backed with freely convertible foreign assets.

CBBH bears the costs of handling the foreign currency and invests the funds for coverage as deposits in foreign banks according to its own business policy on a commercial basis.

Inflation has been low and stable and BAM has become the major transaction currency. Kovacevic (2003) accounts for the success of the currency board with four factors. First, the population values a stable currency; second there is complete trust in the anchor currency; third $\mathrm{CBBH}$ has a foreign governor which has established its political 
neutrality; and finally, its legal requirements are very specific and independent and make it impossible to extend credit and lending to the government.

In Bulgaria, the Currency Board was established in 1997 in Chapter 5 of the Law on the Bulgarian Central Bank which fixed the exchange rate of the lev. Only an act of the National Assembly can change the peg. The lev is fixed to the Euro. Full exchange cover is required for the total amount of monetary liabilities, that is the aggregate amount of domestic liabilities shall not exceed the lev equivalent of gross international foreign reserves. Inflation and exchange rate devaluations in the early years of the currency board led to it accumulating excess coverage. The currency board was established within the framework of the existing central bank and a government deposit, although for sterilisation purposes, is included in its balance sheet. The board is independent and is unable to extend credit to the state unless it is against the purchase of SDRs from the IMF. The Governor is elected by the National Assembly which also, on his recommendation, elects 3 deputies. The other 3 members are appointed by the President. The currency board can only extend credit to banks where liquidity risk has systemic implications and it may only perform the lender of last resort function using the minimum reserve requirement.

In the formulation of economic and monetary policies, the government and the board are required to inform each other of their intentions and actions.

The Hong Kong currency board arrangements began with the Exchange Fund Ordinance and have been continued under the Basic Law. Until 1988 currency was the only monetary liability of the authorities and bank reserves were held at HSBC which at the time managed the clearing house. Between 1988 and 1996 these were held in an account HSBC was required to accept on the books of the Exchange Fund. When the monetary base was finally defined in the 1998 reforms of the currency board system, it was currency, the aggregate balance of the banking system and Exchange Fund Bills and Notes. Reserve funds may be in domestic or foreign currency or gold or silver. Liquid \$US assets are used. The liabilities to be backed are the Fund's Certificates of Indebtedness (Cis). The convertibility is set at HKD7.80 $=\$$ US1, but only the cash component of the monetary base is guaranteed two-way convertibility. It may act as lender of last resort for systemic purposes.

Reflections on these three cases suggest that the degree of independence from the government of the day is very much dependent on the enabling legislation and the involvement of the board in a domestic banking crisis depends on how the lender of last resort issue is defined in the legislation. The requirement of immediate access to reserves and what defines reserves is also very case-specific.

We now consider the Bosnia-Herzogovina Currency Board in the light of Ayken's theory and our extension of it. As a transition economy with no previous record, the country's currency board was initially accorded momentary trust by all parties in the foreign exchange market. Following Kovacevic's (2003) discussion of its success we can see that these factors led speedily to reputational trust and by now have led to affective trust as stability continues to be a characteristic of its operations. Market actors assume normality.

\section{Argentina's Currency Board}

We can contrast this situation with that of the currency board of Argentina. The Banco Central de la Republica Argentina's (BCRA) role as a currency board was established under Article 4 of the Convertibility Law of March 1991. Backing assets were freely available reserves defined as gold and foreign exchange reserves. The monetary base comprised the liabilities to be backed. Sales of foreign exchange were to be at the official rate with purchases of foreign exchange at market prices. The BCRA's charter Chapter viii, Article 20 allowed the BCRA to finance the national government through the purchase of marketable Treasury securities at market values with a limit of $10 \%$ on the growth of these holdings and Article 33 added that up to one-third of freely available reserves held as ordinary pledge, could be paid in with public bonds at market prices. Further, part of external assets could be kept outside the BCRA in the form of interest-bearing deposits on or other investments with foreign banking institutions or in low risk high liquidity bonds payable in gold or foreign currency. Although this contributed to profit maximisation it implied that reserves were not necessarily immediately available. In the case of a temporary lack of liquidity in the 
banking system an amount up to the net capital of a borrowing bank could be provided for a duration of up to 30 days, with $125 \%$ guarantee required. Article 17 (b) and 9(c) allowed the granting of rediscounts and overdrafts to banks.

When a terms of trade shock created a recession in Argentina, the recession created was exacerbated by the enforced contraction of the monetary stock by the currency board.

In 2001 the economics minister, Domingo Cavallo who had created the currency board in Argentina, was called back into service by President de la Rua, and he then proposed to make the Euro a backing currency in addition to the \$US. One peso would be equal to \$Us0.50 and Euro 0.50. Canac (2003) provides the following table which compares the impact of a $40 \%$ appreciation of the \$US against the Argentine real and a 20\% appreciation of the Euro against the Euro, under first, the existing convertibility system and, second, under Cavallo's proposal.

\begin{tabular}{|c|c|c|}
\hline Exchange rates & Existing system & Cavallo's proposal \\
\hline Value of peso in reals & $+40 \%$ & $+30 \%$ \\
\hline Value of peso in euro & $+20 \%$ & $+10 \%$ \\
\hline Value of peso in dollars & $0 \%$ & $-10 \%$ \\
\hline
\end{tabular}

Source: Canac (2003)

This table suggests that Argentina's loss of competitiveness would have been less drastic under this proposal., and overall, its effective exchange rate would not have appreciated as much as under the existing system and it would have depreciated $10 \%$ against the \$US. Its effective exchange rate would have been more stable and its terms of trade would not have deteriorated to the same extent.

Reflection on the establishment conditions of the CBRA suggests that changes would not be too difficult. Ho (2002 at p 22) noted that "written laws can be changed-sometimes more easily than one would think" and refers in a footnote on the same page to Argentina and the modification of its Convertibility Law in June 2001 despite an opposition-controlled Senate. This was the change required by Cavallo's proposal. Hanke(2002at p.9) is right that Cavallo's actions "Compromised confidence and credibility" but more because they showed an instability in the existing currency board arrangements than anything else. Investors looking at the structure of the currency board suddenly became aware of how much influence the government could have on it and this lost it its aura of independence.

Gilson (2002) constructs an index of statutory pre-commitment for currency boards to use it as a benchmark to evaluate currency boards.

Against this Argentina's currency board deviates in a number of ways. First, the BCRA Charter in Chapter VIII Article 33 added that up to a third of freely available reserves held as ordinary pledge, could be paid in with public bonds at market prices which implied, according to Gilson, that by law only a fraction of the two thirds of the reserves essentially satisfied the quality and quantity backing conditions. Further a fraction of external assets could be kept outside the BCRA which in Gilson's view meant that the condition for immediate access to full reserves was also not exactly satisfied.

It is surprising that Argentina's currency board was accorded more than momentary trust in the market given the number of deviations from the standard model as Gilson (2002) has identified. Overcoming reluctance initially was the fact that the market perceived it as simply a "currency board" and did not further inquire into its details. Thus the board was able to move from the momentary trust stage to the reputational trust stage quite quickly. Over the course of the 1990s as this shifted to the affective trust stage. The changes proposed by Cavallo constituted the "shock" which lurched the market from cognitive dissonance to moral outrage. The currency board structure ceased to be acceptable to the market actors and this added materially to Argentina's problems. There were early signs of potential difficulty once the original details of the currency board's structure and legislative base were read but it seems that the need to read their detail was overcome by the recognition that it was a currency board and the market 
had a clear set of expectations about the performance of a currency board. Only when these expectations were very seriously violated by Cavallo's actions were the details of the board's structure seen as relevant.

\section{CONCLUSION}

We have set out the elements of Aykens' social theory of currency crisis and suggested that the explicit recognition of disaster myopia and cognitive dissonance may be useful. Aykens' tests his social theory of currency crises on the interwar gold standard crisis. In this paper we have sought not only to extend his theory briefly but to show how it may also be applied to the situation of currency boards. This clearly places Aykens' theory as having relevance in current economic conditions.

\section{REFERENCES}

1. Ashinger, Gerhard (2002) Currency board, dollarisation or flexible exchange rates for emerging economies? Reflections on Argentina Intereconomics, March/April.

2. Aykens, P.(2005) (Mis)trusting authorities: a social theory of currency crises Review of International Political Economy Vol 12 No 2.

3. $\quad$ Becker, L.C. (1996) Trust as noncognitive security about motives Ethics 107.

4. Calvo, G. O. and C.M. Rinehart (2000) Fear of Floating Working Paper 7993 National Bureau of Economic Research.

5. Cohen, Benjamin (1998) The Geography of Money, Cornell University Press, Ithaca.

6. Corden, W. Max (2002) Too Sensational: On the Choice of Exchange Rate Regimes, MIT Press, Cambridge.

7. Crosby, Mark (2001) Currency unions, currency boards and other fixed exchange rate arrangements The Australian Economic Review, Sept.

8. Dasgupta, P.(1988) Trust as a commodity in Diego Gambetta (ed) Trust: making and breaking cooperative relations Basil Blackwell, New York.

9. $\quad$ De Palma, A. (2002) Five questions for Steve Hanke New York Times February 10.

10. Enoch, Charles and Anne-Marie Guide (1998) Are Currency Boards a Cure for all Monetary Problems? Finance and Development, December.

11. Fischer, S. (2001) Exchange Rate Regimes: Is the Bipolar View Correct? Journal of Economic Perspectives vol 15.

12. Flood, R. and N. Marion (1998) Perspectives on the recent currency crisis literature NBER Working Paper \#6380 NBER, Cambridge, Massachusetts.

13. Frankel, J. (1999) No Single Currency Regime is Right for All Countries Or At All Times Essay in International Finance 215, International Finance Section, Princeton University.

14. Ghosh, A.R.., A. M. Gulde and H.C, Wolf (2000) Currency Boards: More than a Quick Fix? Economic Policy, 30.

15. Gilson, M-T. C. (2002) Policy pre-commitment and institutional design: a synthetic indicator applied to currency boards OECD Economics Working Paper No 16, May.

16. Guttentag, Jack M. and Richard J. Herring (1986) Disaster Myopia in International Banking Essays in International Finance, No 164, September.

17. Hamada, Koichi (2001) The choice between flexible exchange rates, capital control and the currency board in Asian countries: A perspective from the 'impossible trinity Japanese Economic Review vol 62 Issue 4, December .

18. Hanke, Steve H. (2002) On dollarization, and currency boards; error and deception Policy Reform Vol 5 (4).

19. Hanke, Steve H. (2002) Currency boards Annals of the American Academy of Political and Social Science Vol 579, January.

20. Hanke, S.H., L. Jonung and K. Schuler (1993) Russian Currency and Finance: A Currency Board Approach to Reform, Routledge.

21. Ho, Corinne (2002) A survey of the institutional and operational aspects of modern-day currency boards BIS Working Paper, No 110, March.

22. Jones, K. (1996) Trust as an affective attitude Ethics 107. 
23. Kaminsky, G.L. and C.M. Reinhart (1999) The Twin Crises: The Causes of Banking and Balance-ofPayments Problems American Economic Review, 89.

24. Kovacevic, D. (2003) The currency board and monetary stability in Bosnia Herzogovina BIS Papers No 17.

25. Leblang, D.A. (2002) The political economy of speculative attacks in the developing world International Studies Quarterly 46.

26. Lewis, J.D. and A. Weigert (1985) "rust as a social reality Social Forces 63.

27. Lyons, B. and J. Mehta (1997) Contracts, opportunism and trust: self-interest and social orientation Cambridge Journal of Economics 21.

28. Mescher, G. (2001) Argentina, the IMF and Currency Boards SVO Research Vol 1, Issue 7, November.

29. Montgomery, J.D. (1998) Towards a role-theoretic conception of embeddedness American Journal of Sociology 104.

30. Nenovsky, Nikolay, Kalin Hristov and Mihail Mihaylov (2002) Comparing the institutional and organisational design of currency boards in transition Eastern European Economics Jan/Feb.

31. Oliva, Maria-Angels (2001) Discipline, signalling and currency boards Review of International Economics Vol 9 Issue 4, November.

32. Perry, G.E. (ed) (1997) currency Boards and External Shocks :How much Pain, How much Gain? World Bank.

33. Pou, P. (2000) Argentina's Structural Reforms of the 1990's Finance and Development 37 no 1.

34. Roubini, Nouriel (1998) The Case against Currency Boards: Debunking 10 Myths about the Benefits of Currency Boards.

35. Stockman, A.C. (1999) Choosing An Exchange Rate System Journal of Banking and Finance,23.

36. .Tversky, A. and Kahneman, D. (1982). Judgments of and by representativeness In Kahneman, D., Slovic, P. and Tversky, A. (eds.), (1982). Judgment Under Uncertainty: Heuristics and Biases. Cambridge: Cambridge University Press; 84-98.

37. Uzzi, B. (1996) The sources and consequences of embeddedness for the economic performance of organisations: the network effect American Sociological Review 61.

38. Walters, A. and S.H. Hanke (1992) Currency Boards in P. Newman, M. Milgate and J. Eatwell (eds) The New Palgrave Dictionary of Money and Finance, Macmillan.

39. Williamson, J.(1995) What Role for Currency Boards? Institute for International Economics.

40. Williamson, J. (2000) Exchange Rate Regimes for Emerging Markets :Reviving the Intermediate Option Institute for International Economics.

41. Wise, C. (2000) Argentina's Currency Board: The Ties That Bind? in C.Wise and R. Roett (eds) Exchange Rate Politics in Latin America Brookings Institution Press.

42. Zucker, L.G. (1986) Production of trust: institutional sources of economic structure, 1840-1920 Research in Organisation Behavior 8. 


\section{NOTES}

